\title{
IMPLEMENTING LEGALLY MANDATED SCIENCE AND PEER REVIEW IN SUPPORT OF THE EVERGLADES RESTORATION PROGRAM
}

\author{
Thomas Fontaine \\ Environmental Monitoring and Assessment Division \\ Garth Redfield \\ Environmental Monitoring and Assessment Division \\ Keith Rizzardi \\ South Florida Water Management District
}

\section{INTRODUCTION}

The Everglades Forever Act set in motion an aggressive program to provide information to support development of a water quality criterion for the nutrient phosphorus $(\mathrm{P})$ in the Everglades Protection Area, the $9000 \mathrm{~km}^{2}$ of remnant Everglades marshes. A $\mathrm{P}$ criterion is an essential regulatory tool needed to begin the process of reversing Everglades $P$ enrichment. The South Florida Water Management District, in close cooperation with other agencies and organizations, undertook laboratory and field experiments, field mesocosm studies, and transect sampling to provide definitive information upon which a P criterion could be rationally based. Water quality and ecological models were also developed to identify $\mathrm{P}$ loads that would achieve a $\mathrm{P}$ criterion. Peer review was an integral part of this scientific endeavor and served to ensure the quality and comparability of data used to develop the $\mathrm{P}$ criterion. Interdisciplinary studies and collaboration were cornerstones of this effort and an open research process improved the flow of high quality information. Definitive data from multiple lines of evidence have been summarized in support of a $\mathrm{P}$ criterion of about $10 \mathrm{ug} / \mathrm{L}$ and, at the same time, publications from these research efforts are contributing greatly to our predictive understanding of subtropical wetland ecology. The case study of $\mathrm{P}$ criterion research in the Everglades provides an excellent example of scientific excellence and open publication in the context of litigation, urgent need, and application to decision support.

Throughout the $20^{\text {th }}$ Century, the United States Army Corps of Engineers, the State of Florida, and the South Florida Water Management District (District), a regional governmental agency serving as local sponsor to the Corps, constructed and operated a massive network of water management structures throughout southern Florida. The Central and Southern Florida Flood Control Project (C\&SF Project), as the system became known, included over 1200 miles of canals, pump stations, and other structures that drained wetlands and diverted waters to provide flood control and water supply for the people of southern Florida. Unfortunately, the C\&SF Project also had significant detrimental effects on the environment, especially to the water quality and hydrology of the Everglades.

Violation of narrative State water quality standards and concomitant biological degradation was alleged in a 1988 lawsuit, known as United States v. South Florida Water Management District, that began a series of events leading to a major scientific effort on Everglades ecology in support of mandated restoration decision-making. As described recently by Rizzardi (in press), after two years of intense litigation the State of Florida had to confront its water quality problems and began an effort to come into full compliance with applicable laws and regulations. Florida's existing state water quality criterion for total phosphorus is a narrative standard that requires "no imbalance in flora or fauna." Although this narrative approach reflects the reality that appropriate nutrient concentrations vary between ecosystems, it also begs the fundamental question for the Everglades: at what point does "imbalance" begin and what scientific evidence is needed to support a decision on "imbalance."

To answer that question, the settling parties and other interest groups developed an historic Settlement Agreement that was subsequently adopted in a Consent Decree. In the document, the parties agreed upon certain numeric limitations for phosphorus in interior areas of the Everglades. In addition, the body of the Settlement Agreement also required the implementation of a research and monitoring program to formally interpret the state's existing narrative water quality criterion for phosphorus. Also required by the Settlement Agreement was construction of large wetlands for retaining phosphorus in runoff from agricultural areas that border the Everglades Protection Area. These constructed wetlands, known as Stormwater Treatment Areas (STA), were designed to 
achieve long-term average total $P$ concentrations of 50 $\mathrm{ug} / \mathrm{l}$ and major reductions in total P loads. STA design was based on published $\mathrm{P}$ accumulation records in areas of the Everglades that received extensive $\mathrm{P}$ runoff.

Additional negotiations and consensus-building efforts eventually produced a Statement of Principles describing a comprehensive effort to begin restoration of the Everglades. The principles of that document were incorporated into the 1994 Everglades Forever Act (EFA), which provides direction and funding to the District and Florida Department of Environmental Protection (the Department) for much of the Everglades restoration effort. The EFA expanded the scope of the restoration to include state lands in addition to the federal lands, imposed new taxes and regulatory requirements on the agricultural areas upstream of the Everglades, and reiterated the need to construct Stormwater Treatment Areas to treat agricultural runoff before it flowed into the Everglades. In addition, the EFA required research on ways to reduce $P$ levels in runoff to values less than $50 \mathrm{ug} / 1$, recognizing that $\mathrm{P}$ concentrations protective of the Everglades were likely closer to $10 \mathrm{ug} / \mathrm{l}$. Recognizing that phosphorus concentrations significantly above background levels in the Everglades have fundamentally altered that ecosystem, the EFA specifically required the Department and District to complete any additional research necessary to "numerically interpret for phosphorus the Class III narrative nutrient criterion necessary to meet water quality standards in the Everglades."

This mandate set in motion an aggressive research program to provide definitive information on the effects of phosphorus on Everglades marshes and to isolate nutrient effects from those associated with hydrology, fire and other factors in marsh ecology. This program also incorporated scientific peer review from the planning stage through project implementation to publication in the open literature. This intensive application of peer review was viewed as an essential quality assurance mechanism to ensure that all research concerning phosphorus effects would be both credible to other scientists and defensible in legal and administrative processes. A major challenge to this entire enterprise was the fact that all this effort needed to be focused on effects at very low phosphorus levels in surface water, on the order of $10-20 \mathrm{ug} / \mathrm{L}$. In fact, if the phosphorus research and rulemaking effort is not completed in time, the EFA includes a default provision. "The phosphorus criterion shall be 10 parts per billion (ppb) in the Everglades Protection Area in the event the Department does not adopt by rule such criterion by December 31, 2003."
This paper provides an overview of the scientific effort on phosphorus effects undertaken to support decisionmaking associated with the Everglades Forever Act. It draws upon the results of one segment of a more encompassing monitoring, modeling and experimental research effort designed to understand and predict wetland hydrology, biogeochemistry, fire dynamics and plant ecology. Summarizing the phosphorus research effort also illustrates the challenges and opportunities in implementing legally-mandated science in a litigious environment with diverse stakeholder perspectives on wetland resources and on the value of science in water resource decision-making. The lessons learned from the scientific process associated with restoration of the Florida Everglades will serve as a valuable guide for researchers and resource managers in other settings.

\section{THE GEOGRAPHIC SETTING}

The Everglades is an internationally recognized ecosystem that covers approximately $9000 \mathrm{~km}^{2}$ $\left(3480 \mathrm{~m}^{2}\right)$ in South Florida and represents the largest subtropical wetland in the United States. The historic Everglades extended from the south shore of Lake Okeechobee to the mangrove estuaries of Florida Bay. More than half of the original system has been lost to drainage and development (Redfield et al., 2001), including the Everglades Agricultural Area (EAA) located south of Lake Okeechobee. Today's remaining Everglades, which are primarily included within the boundaries of the Everglades Protection Area (EPA), are comprised of Everglades National Park (the Park) including Florida Bay and three Water Conservation Areas (WCAs) (WCA-1, WCA-2, and WCA-3) (Figure 1). The areas included in the EPA are the primary targets of the Everglades restoration.

The Park encompasses $5,569 \mathrm{~km}^{2}$ of freshwater sloughs, sawgrass prairies, marl-forming wet prairies, mangrove forests and saline tidal areas at the southern end of the Florida peninsula (Figure 1). Today, Everglades National Park is the second-largest national park in the United States. The Park contains three dominant wetland habitat types-sloughs, marlforming marshes and mangroves. Sloughs comprise much of the central drainage of the park. Southern marl-forming marshes are characterized by the formation of marl soils (also known as calcitic mud). The third major wetland system (mangroves) occupies the southern and western borders of the Park where freshwater ecosystems merge with the brackish estuaries of Florida Bay at the extreme southern tip of mainland Florida. The Bay includes the body of water that lies between the mainland peninsula and Florida Keys. It covers a total area of about $2,200 \mathrm{~km}^{2}$ of 


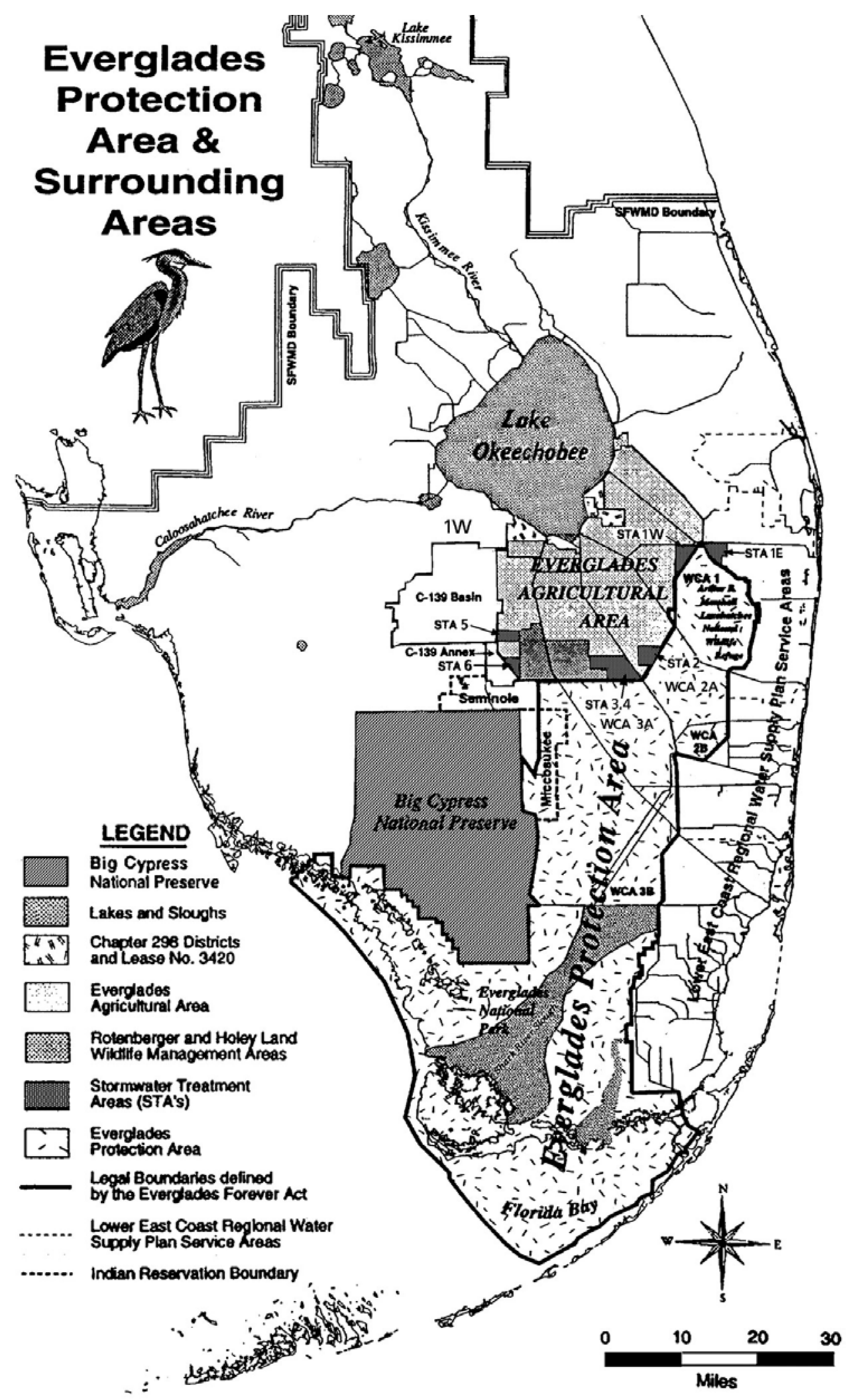

Figure. Everglades Protection Area and Surrounding Areas. 
which approximately $1,800 \mathrm{~km}^{2}$ lie within the Park. Florida Bay is a broad shallow expanse of brackish to salty water that contains numerous small islands, extensive sandbars and grass flats.

The three WCAs are major components of the EPA and an important source of water supply for South Florida. The WCAs, located south of Lake Okeechobee and east of the heavily urbanized Lower East Coast, comprise an area of about $3,497 \mathrm{~km}^{2}$ (Figure 1). Water Conservation Area 1 (WCA-1) is within the Arthur R. Marshall Loxahatchee National Wildlife Refuge (Refuge) and covers an area of 566 $\mathrm{km}^{2}$. The Refuge has been the subject of extensive monitoring and some research. Water Conservation Area 2 is an extensive sawgrass wetland that encompasses an area of $537 \mathrm{~km}^{2}$. More than half of the inflow water entering WCA-2A originates from the EAA. Canal inflow waters are highly mineralized and contain high concentrations of nitrogen and phosphorus resulting from the oxidation of organic peat soils and fertilizer application within the EAA. WCA-2A has been the site of intensive ecological research and water quality monitoring. Finally, the largest of the water conservation areas, WCA-3, covers an area of $2,339 \mathrm{~km}^{2}$ (Figure 1). The area is predominantly a vast sawgrass marsh dotted with tree islands, wet prairies and aquatic sloughs.

\section{EVERGLADES ENVIRONMENTAL PROBLEMS}

The EPA encompasses what remains of a once larger Everglades ecosystem. Urban and agricultural development during this century has reduced the present-day Everglades to 50 percent of its original size (Mitsch and Gosselink, 1993). Beyond the loss of spatial extent, the biotic integrity of the remaining Everglades is also endangered due to undesirable changes in water quality, flora and fauna in portions of the EPA during the last several decades. These changes include: (1) establishment of pronounced nutrient gradients in the WCAs downstream of major discharge structures; (2) replacement of large areas once dominated by sawgrass and periphyton with cattail; (3) decline in wading bird populations; and (4) species changes in periphyton and macroinvertebrate communities (Belanger et al., 1989; Davis 1991, 1994; Ogden, 1994; Walker, 1991). These environmental impacts have been attributed to urban and agricultural development, a disruption of the system's natural hydroperiod and an introduction of nutrient-rich runoff to the EPA from the $2,800 \mathrm{~km}^{2}$ Everglades Agricultural Area (EAA). In addition, the heavy metal mercury is a potential challenge to Everglades restoration. Mercury has been found in ecologically significant quantities in many sites throughout the EPA and has caused the issuance of fish consumption advisories over large areas of the ecosystem. A long-term, multi-agency program has contributed greatly to our understanding of this toxic metal in South Florida; findings from this research and monitoring on mercury are detailed in Atkeson and Parks (2001), along with a guide to the large body of resulting publications.

These environmental problems have led to a call for restoration of the Everglades ecosystem as a national, even international, imperative. The Florida Legislature stated the mandate succinctly:

“...the Everglades ecological system not only contributes to South Florida's water supply, flood control, and recreation, but serves as the habitat for diverse species of wildlife and plant life. The system is unique in the world and one of Florida's great treasures. The Everglades ecological system is endangered as a result of adverse changes... and, therefore, must be restored and protected." (Everglades Forever Act [Act; Section 373.4592, F.S. as amended])

Although this massive undertaking is unique in scale and complexity, it follows a well-worn path of environmental management addressing the manifestations of excess nutrient inputs (Carpenter et al. 1998; Smith et al. 1999) and is based upon a foundation of excellent science, particularly on the many ramifications of eutrophication. The District, in partnership with other agencies and private landowners, is aggressively and successfully achieving interim milestones toward restoration of the Everglades ecosystem based on sound science. Concurrent with the construction of more than 42,000 acres of treatment wetlands, known as Stormwater Treatment Areas, or STAs, the District and other groups are conducting water quality research, ecosystem-wide planning and regulatory programs to ensure a sound, scientific foundation for decision-making. Florida's 1994 Everglades Forever Act establishes both interim and long-term water quality goals to ultimately achieve restoration and protection of the EPA. The Act recognizes that additional measures may be required to achieve compliance with long-term water quality standards. The interim program encompasses those activities underway to reduce phosphorus (P) concentrations to a long-term average of 50 parts per billion (ppb), and includes the Everglades Construction Project and Everglades Agricultural Area best management practices. The long-term goal is to combine point-source, basin-level and regional solutions in a system-wide approach to ensure that all waters discharged to the EPA are achieving water quality goals by December 31, 2006. With respect to nutrients, the long-term goal is to reduce nutrient dis- 
charges to levels that do not cause an imbalance in natural populations of aquatic flora or fauna. The large research and monitoring program done to support a science-based numerical interpretation of imbalance is the main focus of this paper.

\section{THE EFFECTS OF PHOSPHORUS ON EVERGLADES MARSHES}

Research to predict the many effects of eutrophication was conducted in full recognition that the EPA ecosystem has been fundamentally altered by humans. The hydrology and interconnections of the ecosystem have been changed greatly by water management projects; the remnant Everglades marshes that are contained in the EPA represent only about one-half of the original Everglades landscape. In this ecological context, research and modeling on the role of hydrology, nutrients, fire, exotic species invasions, mercury fate and transport have increased understanding of this subtropical marsh greatly in the decade of the nineties compared to the scientific benchmark on Everglades ecology compiled by Davis and Ogden (1994).

Phosphorus has been identified as the nutrient most responsible for changes in periphyton and plant communities within the EPA (Koch and Reddy, 1992; Davis, 1994; McCormick and O'Dell, 1996; McCormick et al., 1998) and phosphorus from fertilizer has been identified, through isotope studies, as being present in areas of biological degradation. The body of science on $\mathrm{P}$ effects has supported a major effort to control $\mathrm{P}$ inputs through mandates of the Everglades Forever Act. Reducing $\mathrm{P}$ loading to the EPA is central to the strategy for restoring and preserving the Everglades. Agricultural Best Management Practices (BMPs) have been installed in the Everglades Agricultural Area and have proven successful at reducing $\mathrm{P}$ loading from that basin. Wetlands for stormwater treatment are being constructed as the second line of nutrient cleansing for the Everglades Protection Area. Research is underway to examine the ability of advanced treatment systems (biological, chemical and hybrid systems) to supplement BMPs and constructed wetlands for $\mathrm{P}$ reduction.

Trade-offs between the effects of nutrients, fire and hydrology must be understood for the establishment of a numeric criterion for $P$ concentrations and successful reversal of marsh eutrophication. Research at several spatial scales has provided an excellent information base for $\mathrm{P}$ effects and hypothesis-driven experiments were deemed essential to establish cause and effect linkages. Although not common for applied agencies, such experimental work is vital when multi-million dollar programs are at stake (see Havens and Aumen, 2000). Experiments using field mesocosms (Newman et al. 1996) provided important evidence regarding the competitive advantage of cattails (Typha spp). Newman et al. (1998) used a comparative approach to determine that fire and hydrology can each influence the expansion of cattails at various locations. The nutrient history of an area appears to be the major factor determining which of these three variables is most important and hydrology tends to promote cattail expansion when $\mathrm{P}$ background levels are higher. In research along a nutrient gradient in WCA-2, Miao and Sklar (1998), and Miao and DeBusk (1999) observed that the effects of enrichment are clearly reflected in plant physiology and community structure.

Everglades periphyton is an excellent indicator of phosphorus enrichment (e.g., McCormick and Scinto, 1999). Studies of periphyton in WCA-2 along a nutrient gradient documented the effects that spatial changes in phosphorus levels had on species composition and productivity (Grimshaw et al. 1993; McCormick et al. 1996; McCormick et al. 1998). These results are consistent with those of McCormick and O'Dell (1996) using synoptic field experiments. Findings from this body of work are placed along the nutrient gradient in WCA-2A in Figure 2. Laboratory, mesocosm and field studies all contribute our ability to predict changes in ecology associated with the nutrient gradient (Payne et al., 2001). Placing the science into a gradient also allows us to predict changes that might reflect imbalance begin to occur above about $10 \mathrm{ug} / \mathrm{L}$, the default threshold of the Everglades Forever Act. It is also noteworthy that multiple lines of evidence from microbial parameters to macrophyte community dynamics all support the $10 \mathrm{ug} / \mathrm{L}$ P criterion.

The results of these studies and many others on the Florida Everglades are being synthesized using mathematical models including landscape models. For example, one version of the Everglades Landscape Model, the Conservation Area Landscape Model (Fitz and Sklar, 1999) has been used to look at tradeoffs between the effects of nutrients, hydrology and other factors. Evaluations using this model suggest that available nutrients increase during drier conditions and can alter productivity without additional external nutrient loading. Likewise, the Everglades Water Quality Model helps to predict the regional transport and fate of P (Raghunathan et al., In press). These models promise to aid in predicting responses of this complex ecosystem to reduced phosphorus loads and will undoubtedly contribute to both Everglades science and decision-making in coming years. 


\section{General ecological changes along the WCA-2A gradient (Summary of threshold research \& monitoring, 1994-1997)}

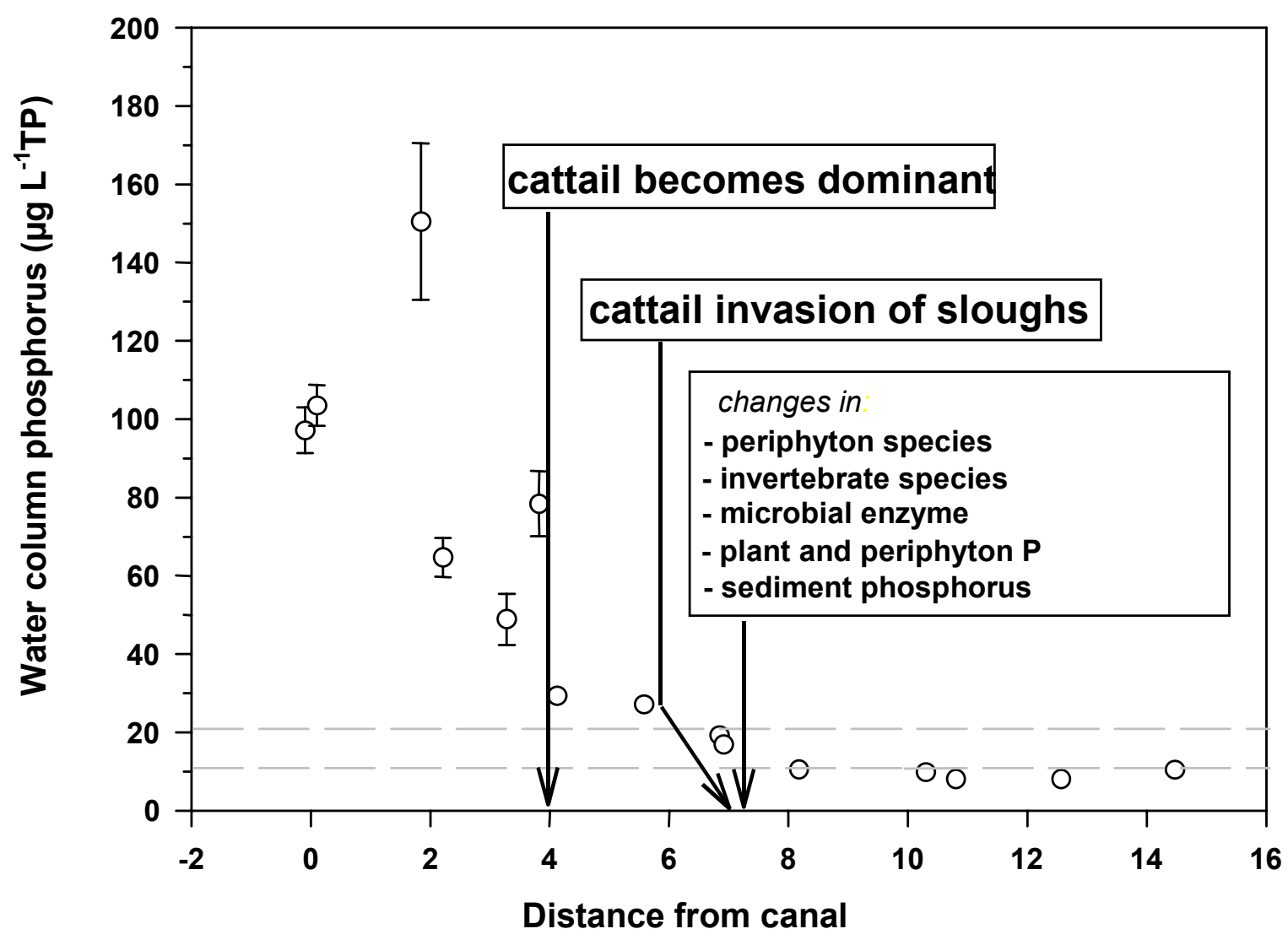

The Florida Department of Environmental Protection has taken the lead in synthesizing information supporting the $\mathrm{P}$ threshold criterion for the Everglades. Their summary can be found in Payne et al. (2001) and earlier editions of the Everglades Consolidated Reports (South Florida Water Management District, 1999). Melding information from experiments, field sampling, modeling and remote sensing done by various agencies and organizations into a cohesive picture of $\mathrm{P}$ effects provides an excellent example of science-based decision support. The weight of evidence supporting a $\mathrm{P}$ criterion of about $10 \mathrm{ug} / \mathrm{L}$ is impressive and the whole body of evidence is far greater than the sum of individual studies. Nevertheless, there are diverse opinions on how the data should be interpreted and what statistical approaches are most informative for rule development.

\section{PEER REVIEW IN THE PROCESS OF EVERGLADES SCIENCE}

History brings a legacy of special interests into the decision-making process with varying perspectives on how science should be involved. The public often does not understand the uncertain nature of science and finds it all too easy to mistrust research scientists (Redfield, 2000). High quality, peer-reviewed science tends to build public trust and is the only kind of science that can stand the legal and scientific scrutiny that are often a part of management decisions. As courts are forced to deal with complex technical information and conflicting claims, they seek scientific information that has been subjected to objective testing and peer review (Ayala and Black, 1993). Open review of programs, projects and publications has played an important role in the science-management relationship in south Florida, as illustrated in the 
following examples. In 1997, under the auspices of the Florida Department of Environmental Protection, a panel of experts reviewed the three Everglades research programs conducting investigations related to the effects of $\mathrm{P}$ on Everglades flora and fauna. They provided helpful guidance to the groups, particularly on ways to make the research results inter-comparable. South Florida Water Management District took a somewhat unique position for an applied agency by encouraging open dissemination of information generated by its research staff and contractors through publication in peer reviewed journals. This process has increased the availability of agency-funded science and has resulted in an impressive level of publication for Everglades science (Redfield, 2000). Another excellent example of peer review is the annual panel review of the Everglades Consolidated Reports (Available at www.sfwmd.gov/org/ema/everglades). In this process, authors present their chapters to the panel and public in a workshop setting, then revise the chapters based upon this intense scrutiny before delivering the report to the Governor and Legislature each January. In any form, review serves to improve the quality and focus of research and monitoring efforts; its application to management-oriented studies is just as appropriate as it is for more academic research pursuits.

The value of high quality in management-relevant science goes beyond legal issues or decision-making: it helps to foster and support equity and long-term sustainability in resource management. Review alone cannot rebuild or maintain public credibility in resource decision-making. However, the use of peer review as an on-going quality assurance tool in applied research leads to information that can not be distorted easily by special interests or systematically ignored by decision-makers. Such excellence in managementdriven scientific research tends to support wise resource management decisions that benefit the public in the short and long-term.

\section{LEGALLY-MANDATED SCIENCE: OBSTACLES AND OPPORTUNITIES}

Looking across the examples of eutrophication-related research in the EPA provides instructive guidance for research planning, execution and publication. The Settlement Agreement of the 1988 lawsuit United States vs. South Florida Water Management District catapulted the District into a research program with deadlines derived by political means, not rational research planning (e.g, Reckhow and Aumen, 1996). The 1994 Everglades Forever Act specified that research in support of a $\mathrm{P}$ criterion for the EPA must be completed by December, 2001. This aggressive mandate forced vigorous planning and implementation to be conducted with the simultaneous implementation of laboratory and mesocosm experiments, field transect studies and ecological modeling, all being done with substantive peer review, public comment and publication in the open scientific literature. Although a challenge in practice, this aggressive execution of the $\mathrm{P}$ criterion research created a critical mass of focused scientific talent and resulted in many of the publications cited earlier and others chronicled by Payne et al. (2001). Thus, the challenge of artificial deadlines became an opportunity for science in South Florida to produce excellent fundamental contributions to the environmental sciences, while contributing directly to the reduction of uncertainty for decisionmaking in ecosystem management (Redfield, 2000).

The overall scientific challenge of the mandated $\mathrm{P}$ criterion research was to provide definitive data across spatial scales from laboratory vessels, to mesocosms, to ecosystem-level sampling, while establishing cause and effects linkages that would stand the intense scrutiny of rule-making for standard setting. Collaboration with regional universities and between researchers in multi-disciplinary teams was the real key to success, but proved awkward for scientists used to working on smaller scale, individual research projects. When the role of science is to reduce uncertainty for ecosystem management, isolated research projects alone cannot provide system-level predictions needed by decision-makers.

The keen interest of the public in Everglades phosphorus research created an awesome burden of communication for scientists working on the mandated program. Being forced to draw conclusions on partially completed projects at public workshops and interagency meetings made researchers uncomfortable, and rightfully so. Presentations before various Everglades committees, such as the EFA-mandated Technical Oversight Committee, and public workshops were also very time-consuming and may have even added some delays to key projects. Furthermore, maintaining credibility to audiences peppered with special interests and with highly diverse viewpoints on the role of science proved to be another real challenge. This was particularly the case as scientists attempted to be honest brokers of information often associated with high levels of uncertainty. Minimizing the existence of uncertainty would be scientifically inappropriate, while too much emphasis on uncertainties would lead to a loss of credibility in the eyes of non-scientists. The benefit of such mid-stream synthesis and critique, however, was a honing and refocusing of research programs and publications through constructive criticism that under most circumstances would only have occurred during peer review of final products. In 
our judgment, the trade-off of the burden to scientists and added value to science was positive, and more science of higher quality was produced as a product of this open research process.

\section{AUTHOR}

Dr. Thomas D. Fontaine is the Director of the Environmental Monitoring and Assessment Division and former Director of the Everglades Systems Research Division at the South Florida Water Management District. He holds a Ph.D. in Systems Ecology and M.S. in Environmental Biology, both from the University of Florida.

In his eleven years at the South Florida Water Management District, Dr. Fontaine has been instrumental in providing a scientific basis for initiating and documenting the effects of environmental management actions. With his two divisions and others he has designed constructed wetlands (Stormwater Treatment Areas, STAs) for retaining Everglades Agricultural Area (EAA) nutrient runoff, developed models for judging EAA compliance with phosphorus runoff rules, developed water quality and ecological models for predicting how the Everglades ecosystem will respond to changes in hydrology and nutrient conditions, and has been documenting landscape Everglades vegetation changes through aerial photo interpretation and satellite imagery. He has also directed research efforts to identify phosphorus levels that will protect native Everglades flora and fauna from imbalance. This research will provide the scientific underpinning for rule making by the State's Environmental Regulation Commission, and will provide a numeric goal for additional nutrient reduction technologies. He has directed research to determine salinity restoration goals for Florida Bay, and to understand and predict the effects of water management decisions on salinity, nutrient, and ecological conditions of Florida Bay and its adjacent mangrove wetlands. Finally, his Environmental Monitoring and Assessment Division is gearing up to assess the effects of the $\$ 8 \mathrm{~B}$ Comprehensive Everglades Restoration Program over the next 30 years.

\section{REFERENCES}

Ayala, F.J. and B. Black, 1993. Science and the Courts. American Scientist 81:230-239.

Belanger, T.V., D.J. Scheidt, and J.R. Platko II, 1989. Effects of Nutrient Enrichment on the Florida Everglades. Lake and Reservoir Management 5:101-111.
Carpenter, S.R., N.F. Caraco, D.L. Correll, R.W. Howarth, A.N. Sharpley and V.H. Smith, 1998. Nonpoint Pollution of Surface Waters with Phosphorus and Nitrogen. Ecological Applications 8:559-568.

Davis, S.M., 1991. Growth, decomposition, and Nutrient Retention of Cladium Jamaicense Crantz and Typha Dominensis Pers. in Florida Everglades. Aquatic Botany 40:203-224.

Davis, S.M., 1994. Phosphorus Inputs and Vegetation Sensitivity in the Everglades. In: Everglades: The Ecosystem and Its Restoration. S.M. Davis and J.C. Ogden (Editors). St. Lucie Press, Delray Beach, FL, pp. 357-378.

Davis, S.M. and J.C. Ogden (eds.), 1994. Everglades: The Ecosystem and Its Restoration. St. Lucie Press, Delray Beach, FL.

Fitz, H.C. and F.H. Sklar, 1999. Ecosystem Analysis of Phosphorus Impacts and Altered Hydrology in the Everglades: a Landscape Modeling Approach. In: Phosphorus Biogeochemistry in Subtropical Ecosystems. K.R.Reddy, G.A. O'Connor and C.L. Schelske (Editors). Lewis Publishers, Boca Raton, FL., pp. 585-620.

Grimshaw, H.J., M. Rosen, D.R. Swift, K. Rodberg, and J.M. Noel, 1993. Marsh Phosphorus Concentrations, Phosphorus Content and Species Composition of Everglades Periphyton Communities. Archives for Hydrobiology 128 257-276.

Havens, K. and N. Aumen, 2000. Hypothesis-Driven Experimental Research is Necessary for Resource Management. Environmental Management 25:1-7.

Koch, M.S., and K.R. Reddy, 1992. Distribution of Soil and Plant Nutrients Along a Trophic Gradient in the Florida Everglades. Soil Science Society of America Journal 56:1492-1499.

McCormick, P.V., and M.B. O'Dell, 1996. Quantifying Periphyton Responses to Phosphorus in the Florida Everglades: a Synoptic Experimental Approach. Journal of the North American Benthological Society 15:450-468.

McCormick, P.V., R.B.E. Shuford III, J.G. Backus, and W.C. Kennedy, 1998. Spatial and Seasonal Patterns of Periphyton Biomass and Productivity in the Northern Everglades, Florida, U.S.A. Hydrobiologia 362:185-208.

Mitsch, W.J., and J.G. Gosselink, 1993. Wetlands- 2nd edition. Van Nostrand Reinhold, New York, New York.

Nearhoof, F.L., 1992. Nutrient-Induced Impacts and Water Quality Violations in the Florida Everglades. Florida Department of Environmental Protection, Water Quality Technical Series Vol. 3, No. 4. 
Ogden, J.C., 1994. A Comparison of Wading Bird Nesting Colony Dynamics (1931-1946 and 19741989) as an Indication of Ecosystem Conditions in the Southern Everglades. In: Everglades: The Ecosystem and Its Restoration. St. Lucie Press, Delray Beach, FL. S.M. Davis and J.C. Ogden (Editors), pp. 533-570.

Payne, G., T. Bennett and K. Weaver, 2001. Chapter 3. Ecological Effects of Phosphorus Enrichment in the Everglades. In: \# South Florida Water Management District, West Palm Beach FL. January 1, 2001. Available at www.sfwmd.gov/org/ema/everglades.

Raghunathan, R.K., T. Slawecki, D.W. Dilks, V. J. Bierman, Jr., S. Wade, T.D. Fontaine, and Z. Chen, (in press). Exploring the Dynamics and Fate of Total Phosphorus in the Florida Everglades Using a Calibrated Mass Balance Model. Ecol. Modelling.

Reckhow, K.H. and N.G. Aumen, 1996. Decision Analysis to Guide Lake Okeechobee Research Planning. Journal of Lake and Reservoir Management 12:78-90.

Redfield, G.W. 2000. Ecological Research for Aquatic Science and Environmental Restoration in South Florida. Ecological Applications 10:990-1005.
Redfield, G., G. Goforth and K. Rizzardi, 2001. Chapter 1. Introduction to the 2001 Everglades Consolidated Report. In \# South Florida Water Management District, West Palm Beach FL. January 1, 2001. Available at www.sfwmd.gov/org/ema/everglades.

Rizzardi, K., in press. Translating Science into Law: Phosphorus Standards in the Everglades. Florida Law Review.

SFWMD, 1999. Everglades Interim Report. South Florida Water Management District, West Palm Beach, FL. January 1, 1999. Available at www.sfwmd.gov/org/ema/everglades.

Smith, V.H., G.D. Tilman and J.C. Nekola. 1999. Eutrophication: Impacts of Excess Nutrient Inputs on Freshwater, Marine and Terrestrial Ecosystems. Environmental Pollution 100:179-196.

Walker, W.W., Jr., 1991. Water Quality Trends at Inflows to Everglades National Park. Water Resources Bulletin 27:59-72. 